\title{
Archaeological Research in Conflict Areas: Practice and Responsibilities
}

\author{
Marlies Heinz, Albert-Ludwigs University, Werthmannplatz 3, \\ 79184 Freiburg, Germany \\ E-mail: marlies.heinz@orient.uni-freiburg.de
}

\begin{abstract}
This paper discusses the relationships between ethics and archaeological fieldwork. It represents the author's reflections on her own archaeological work in an area, Lebanon, which has in recent times been wracked by considerable violence. The stimulus for the paper came mainly from the question posed by the session organizers and editors of this issue: what would constitute ethical archaeological practice, especially in situations of war and violence but also in cultural contexts in which different approaches to understanding and valuing historical knowledge predominate than those typically held by archaeologists. Two concrete examples from my own fieldwork in Beirut and Kamid el-Loz make clear how the scientific interests of historical-archaeological research and those of people who live in the research area can be reconciled despite specific instances in which they diverge.
\end{abstract}

Résumé: Cet article traite de la relation entre l'éthique et le travail de terrain archéologique. II représente les réflexions de l'auteur sur son propre travail archéologique dans un lieu, le Liban, qui a récemment été secoué par une considérable violence. Le point qui a présidé à la rédaction de cet article provient essentiellement de la question posée par les organisateurs et les éditeurs de ce problème: qu'est-ce qui constituerait une pratique archéologique éthique, tout spécialement dans un contexte de guerre et de violence, mais aussi dans les contextes culturels pour lesquels différentes approches de compréhension et de mise en valeur de la connaissance historique est typiquement du ressort des archéologues. Deux exemples concrets de mon propre travail de terrain à Beyrouth, et à Kamid el-Loz, éclaircissent la façon dont les intérêts scientifiques de la recherche historicoarchéologique et les personnes qui vivent dans le lieu faisant l'objet des recherches peuvent être réconciliées en dépit du fait de leur divergence dans des cas spécifiques. 
Resumen: En este trabajo se analizan las relaciones entre la ética y el trabajo de campo arqueológico y recoge las reflexiones del autor sobre su propio trabajo arqueológico en un país, Líbano, que hace poco fue devastado por una violencia extrema. El estímulo para redactar este trabajo procede principalmente de una pregunta planteada por los organizadores de la sesión y los editores de este ejemplar: qué se entiende por práctica arqueológica ética, sobre todo en situaciones de guerra y violencia, pero también en contextos culturales en los que existen distintos enfoques para entender y valorar el conocimiento histórico que predominan sobre los defendidos por los arqueólogos. Dos ejemplos concretos de mi propio trabajo en Beirut y Kamid el-Loz dejan claro que es posible reconciliar los intereses científicos de la investigación histórica y arqueológica y los de las personas que viven en la zona de investigación, a pesar de las circunstancias específicas de cada uno.

\section{KEYWORDS}

Multiple audiences, Multiple viewpoint, Multiple voices, Critical reflexivity, Plurality

\section{Ethics and Identity}

This paper discusses the question of correct action with regard to ethics: as archaeologists, which practices should we pursue? More than ever the present plurality of cultural worlds and worldviews complicate the shaping of opinion on what ethical practice is. Establishing a clear-cut, normative framework and guidelines for practices seems quite difficult, if not impossible (Hamilakis 2007). After a general discussion of this issue, I describe two concrete situations from my fieldwork in Lebanon to illustrate the scope of this question.

A solution to the question of what ethical action is cannot be found in our practical, on-site archaeological work alone nor in a detached armchair analysis of the way we conduct our fieldwork. Nor does reflection upon how our excavation results could be exploited, including what we might consider beneficial use or abuse, provide an answer. In fact, the quest for an answer to what appropriate archaeological practices are begins at the point when we choose our occupation, because that already constitutes an acknowledgment that history and the past are of interest in at least two ways. First, an investigation of the past is of fundamental interest because there is some meaning in history. And second, such a search for meaning 
in the past is worth a substantial part of one's own energy and time, indeed, it occupies a "professional life."

History or historical knowledge is not just 'out there'. It is a relation between the past and the present. The point is to recognize that every society and every generation has to conduct their own evaluations of the past in relation to a constantly changing present and to look forward from that relational exploration. We should therefore investigate how and why reconstructions and interpretations of the past are accomplished and by whom; equally important is a consideration of the power of those who decide who is allowed to present their memories and stories of the past to a larger audience.

Any political situation and any social constellation has its own preconditions and backgrounds. In my opinion, we have to search for situational solutions that respect the interests of all involved in archaeological work in every single case. There are two frames within which we work. The first is constituted by the antiquities laws of the respective countries where we work, laws that stipulate both duties and rights of archaeologists, workers on excavations, government representatives, and others. ${ }^{1}$ Second, the particular situations in which we work may require some special negotiations that can narrow down the legal framework further. A local powerholder may have reservations about the excavation of specific buildings from the recent past. In this case, a negotiated solution among the diverging interests of archaeologists and non-professionals is necessary. However, sweeping generalizations about the ways to reach such compromises are unwarranted. That does not mean that we can dispense with addressing the social and political implications of our work. As stated in the original invitation to the session from which this paper derives: "We need to confront the question of what is at stake in the production of archaeological knowledge."

At the most general level, we might define what archaeology does as the production of knowledge. More precisely: archaeologists produce a particular kind of knowledge-one that may serve as a base for constructing both the historical past and present conditions as well as larger views of the world and specific identities.

This means that as archaeologists we take part in the process of generating worldviews. We produce knowledge, and this knowledge can be used for the most manifold intentions and aims. Consequently, our production of knowledge cannot be labelled as 'neutral' or 'objective'. In dedicating ourselves to archaeology, we recognise the importance of historical information and historical knowledge for (western) societies and groups with worldviews that are compatible with such ideas. By doing so, we accept the esteem such (western) societies have for this kind of knowledge. We consider the method of our production of knowledge to be intellectual and 
scholarly. This means that our way of producing knowledge is based on reason and discourse: our information may-ideally-be interpreted and re-interpreted by anybody and thus provides a potential platform for a plurality of meanings.

\section{The Case of Lebanese Archaeology}

All three aspects mentioned above-lack of neutrality and objectivity, a predisposition to acknowledge an inherent value to history, and a general openness to alternatives in the interpretive realm-played a role in my fieldwork at two locations in Lebanon, in Beirut and Kamid el-Loz. The excavation in downtown Beirut was made possible because many areas of the city lay in ruins after 15 years of civil war (1975-1990). Ironically, it was the result of the civil war that allowed for any archaeological research at all.

At the beginning of our excavations in Beirut, neither politicians nor residents were interested in the archaeological exploration of the city center. There are at least two reasons for this. First and foremost were the economic interests of the building industry and politicians alike, and second the reluctance of the residents to recall "the past" - a well-known phenomenon in any post-war society (Ellis 2002). In contrast, a promising option for a good future was seen in the swift rebuilding of downtown Beirut. The visible construction of the new was also propagated as a chance to establish a new identity for the inhabitants of Beirut and even of the Lebanese people as a whole, and it was seen as a support for overcoming the division of society brought about by a civil war that lasted from 1975 to 1990. Some of the main reasons for the war lay in the colonial construction of the country, a piece of land carved out of a larger entity and whose majority was initially of Christian belief. Demographic shifts involving a shrinking Christian and fast growing Shiite population along with the influx of numerous Palestinian refugees produced an explosive mix of diverging interests. Multiple militias of Shiite and Sunni Muslims, Druze, Christians as well as Palestinians fought in the long war, during which downtown Beirut was almost entirely destroyed.

Attitudes toward archaeological fieldwork in Beirut tended at first to be somewhat inimical. Discussions among various stakeholders turned into a drawn-out process. Amongst these groups were Lebanese and foreign archaeologists, colleagues from the Department of Antiquities who had been responsible for the organization and administration of the archaeological activities in the city, as well as residents and the deputies of the Beirut city council. In the end, the feelings of the various parties changed. Residents who were concerned about an encroachment on their properties were paid (admittedly small) indemnities. Urban planners understood that they could 
integrate excavated areas as monuments in the cityscape, and the Direction Générale des Antiquités was willing to give concessions once financing of the projects was cleared through support by Solidère (Curvers 1997), ${ }^{2}$ UNESCO and, for German Projects, the Deutsche Forschungsgemeinschaft. Furthermore, students and archaeological professionals were once again able to conduct research after many years of forced inactivity induced by internal strife and lack of security. The municipality protected a representative portion of the archaeological findings, among them Phoenician, Hellenistic, and Roman remains. These are kept visible in the city as monuments that illustrate the history of Beirut and Lebanon. All parties involved agreed to recognize a specific value of the material legacy of that history. What is more, the long forgotten past helped to submerge the well remembered but publicly repressed immediate past and the horrors of the civil war.

Phoenician, Greek and Roman history provided a platform for identification with a glorious past and with Lebanon as an active and prosperous agent in world politics. Past and the present merged into an imagined continuity in which the Phoenicians' success story could serve as a model for the effective reconstruction of Beirut. Originally propagated in the time of the French Mandate (Ellis 2002), this material as well as narrative construction helps to eclipse the 15 dark years of internal conflict. Archaeology thus became useful for many divergent interests. Politicians and residents used archaeology in order to create a common identity, the building industry and the Department of Tourism to attract visitors and to make money with the "visibility of the past.""

In this particular case, a postulate of the archaeological discipline that visible commemoration and awareness of history are important turned out to be successful, through the active care of the archaeological remains in Beirut by the residents and political exploitation by the municipality. In other words, the residents of Beirut used and interpreted the knowledge produced by archaeology at their own discretion and according to their own imagined associations. Plurality of meanings has been asked for by us as archaeologists—and plurality of meanings has come about!

To date, the historical information conveyed through archaeology provides a platform for putting forward a diversity of opinions, discussions, and interpretations. The archaeological ruins still present in downtown Beirut are used to discuss the history and glory of Lebanon. This is also true for other sites such as Kamid el-Loz, Baalbek, Byblos, Tyre and Sidon. In general, people are aware and proud of the ancient history of their country.

As seen in Beirut archaeological fieldwork therefore means that archaeologists take part in working out often divergent worldviews, whether they wish to do so or not. They believe in the particular value of historical knowledge and furthermore think that there has to be a rationale for the interpretation of historical evidence. Finally, they assume that a variety of 
interpretations is possible (Eggert 2006). Looking at archaeology in that way means that we not only participate in the proliferation and alteration of scholarly knowledge, but also provide tools-which archaeologists themselves cannot control-for the development of identities as well as for the creation of political legitimation. It is then, however, our task to critically accompany such processes of interpretive use of archaeological results.

The ways in which historical evidence is used after the completion of fieldwork and the purposes to which it is put are beyond our control. This loss of control is part of the archaeological discipline's demand for free access to knowledge for everybody. However, this does not dispense with a responsibility on our part to follow this process with critical attention.

\section{The Production of Knowledge at Kamid el-Loz}

In describing the basic principles of our activities and the role that archaeology plays in society we become aware of the fact that our ways of producing knowledge are not the only possible ones. We should acknowledge that other cultural, religious, and class contexts have their own approaches towards the creation of history, identity, and knowledge. As archaeologists we regard the plurality of production of knowledge as beneficial. The academic setting of our discipline, and thus a penchant towards critique, should ensure the recognition of a certain disharmony in the past. At the same time, we confront the situation that we live in or have contact with social groups, political systems, or subcultures where there may be a rather homogeneous worldview and one in which the construction of history and the past—and the shaping of ideology—are communicated predominantly by narratives of religion, traditional customs, or esoteric discourse. Such an encounter between two different perceptions of the value of history may be illustrated by working conditions in Kamid el-Loz: on the one hand, our concern to uncover history and historical knowledge and thus to show alternative forms of social organization, and on the other hand the request of some of the local authorities to reconfirm a worldview that reflects their concept of order and suppresses competing ideas in the process.

The early excavations at Kamid el-Loz in the Beqa'a valley were discontinued in 1980 because of the civil war. Fieldwork was resumed in 1996 when the internal conflict was definitely over. Our work, that is a project involving an international group of Lebanese, Jordanian, Swiss, Italian, Albanian, French, Austrian, U.S. American, Canadian and German researchers and students at Kamid el-Loz, has again been interrupted in 2006, when the territory of Lebanon was abused as a battleground for yet another war. The renewal of excavations in Kamid el-Loz after the end of the civil war were welcomed by the population as well as by the local 
administration. The sector of excavations neither touches housing areas nor farm or grazing land. Consequently, the excavation does not present any economic burden for the village but is rather seen as an advantage because of short-term employment opportunities and possibilities to develop a small tourist attraction that could bring in additional revenues.

In the course of our excavations in Kamid, few of the local religious authorities raised the question whether it was desirable to expose the evidence of pre-Islamic settlement activities at the site and thus bring to light the history of pre-Islamic cultures in the area. All parameters mentioned above for the Beirut example could have been effective in Kamid el-Loz as well. Archaeological material could have been used for stabilizing identities; ruins could have been part of the production of worldviews that include a visualization of historical memory. History and archaeology, useful and usable as described, would thus obtain prime importance for the local religious authorities to achieve their political aims.

However, the current political, economic, and cultural conditions in the Beqa'a Valley make the process of reconstructing a past even more politically relevant than in Beirut. The Beqa'a Valley is inhabited by Muslims and Maronite Christians alike. The economic situation is tense, the unemployment rate high. The representatives of both religions compete for political influence and power, with Muslims holding the majority among the population. The most recent conflict, the bombing by Israeli forces in the summer of 2006, unveiled the latent tension between the religious communities once again. Visible evidence for a community from Islamic times would be politically desirable for one group, reinforcing their identity, and be politically exploitable as a proof for the long history of Islamic history and culture in the area.

However, the desire to keep Islamic evidence visible on the site at the same time implied the impossibility of excavations of any older levels. In addition, exposing older settlements would qualify the Islamic culture as only one part in a long cultural development of various traditions and complicate the construction of local identity and its use for political purposes by one of the concerned groups. Thus, a differently interested approach to the past, the archaeological one which ideally tends not to 'favor' specific periods, runs counter to local views of the value of the past. ${ }^{4}$

As long as archaeology with its specific ways of producing knowledge supports the locally dominant worldview, it is considered helpful. However, where the archaeological evidence foils the political concepts of the local authorities, it runs the risk of becoming troublesome-with consequences for archaeological research itself. Thus, a local sheikh was concerned that we do not excavate burials that could potentially be from Islamic times. In negotiations, a compromise was reached that we would not excavate more than five such burials per season. When that happens, we stop digging in 
such areas and move on to others where there is no reason to suspect that we will find burials. This compromise suits the interests of both local powers and archaeologists.

\section{Back to Ethics}

Against this background I return to the main question asked at the outset: what is ethical practice for archaeologists when different views about how to deal with access to historical knowledge clash? One could be inclined to believe that as archaeologists we do not have the right to introduce our views about the relevance of history and our knowledge of it to societies with a different esteem for historical knowledge and different approaches to history-especially when importing our ideology and alternative worldviews could threaten to destabilize an already unstable political order.

Two arguments stand against this view. First, considering the presentday technology of communication, we may assume that there is almost no single spot worldwide that is untouched by global TV, mobile phone, and Internet. This means that knowledge about the existence of a diversity of opinion and manifold worldviews is a global given, even without us, the archaeologists. ${ }^{5}$ Second, regardless of the global networks of communication, there are, of course, attempts to limit the flow of information, where influential circles push for the conservation of a pretended traditional closeness and unity of a locally dominant political and cultural ideology (Hobsbawm and Ranger 1983). In such cases, we are normally dealing with political constellations in which decisions about the production and distribution of knowledge are made by small powerful groups such as political and/or religious elites. More often than not they are male.

In Kamid el-Loz, archaeologists and some of the local authorities pursued diverging interests. As during the work in downtown Beirut, we had to be aware of the political impact of our work, and we had to strive for a context-specific solution to the local requests that were put forth. A solution has been found in compromises that satisfy the concerns of all involved-to some extent, but never fully.

\section{Conclusion}

Archaeology is situated in global inter-cultural exchange. The local existence or non-existence of a plurality of meanings and worldviews is - in the light of global developments-no longer a fundamental distinctive feature of contemporary societies (Starzmann 2008). What we may distinguish is rather, how the spokesmen in particular societies deal with the offer of 
and internal demand for plurality and diversity of opinion. The practice of dealing with knowledge and information, provided by archaeologists among others, depends on political decisions.

Being socialised and acculturated as a "westener" and educated to examine the world with a critical consciousness, I place a high value on the plurality and diversity of opinion and knowledge as well as on the guarantee of open access to knowledge for every woman and every man. At the same time, as an archaeologist who works mainly in societies with patterns of acculturation quite different than my own, I am well aware of the fact that the term "plurality of knowledge" and the access to such knowledge are defined and regulated in culturally specific ways.

Under these conditions, every archaeologist has to decide by her/himself how to proceed: whether to give priority to the political intentions of local authorities or, as the author would prefer, to try to convince them of one's own cultural-political preference for plurality, and of the value of cultural diversity and open access to knowledge-including the "risk" (or the chance) to face the truth that one's own way of living is only one among many possible others. Don't we as archaeologists have something to learn in these situations, not just from archaeological research but also from the 'ethnographic' encounter with people we live and work with when in the field?

\section{Notes}

1. The North American Graves Protection and Repatriation Act (NAGPRA n.d.) shows how the concerns of hitherto neglected stakeholders in archaeological excavations became a major element in restricting the unduly wide-ranging rights of the archaeologists.

2. For a highly critical appraisal of Solidère and the Lebanese government's role in the 1990s, see Naccache (1998).

3. The commercial interests of Solidère, founded by the assassinated former Prime Minister Rafik Hariri, are a main focal point of criticism (see Nardella and Abbas n.d.).

4. It is understood that such 'neutrality' can only be striven for but never reached.

5. I do not imply that the knowledge of multivocality leads inevitably to greater acceptance of the values of an Other.

\section{References Cited}

Curvers, $\mathrm{H}$.

1997. Archaeological Resource Management in the Beirut Central District. http://www.nps.gov/history/nagpra/MANDATES/INDEX.HTM. Accessed 6 March 2008. 
Eggert, M.K.H.

2006. Archäologie: Grundzüge einer historischen Kulturwissenschaft. A. Francke, Tübingen.

Ellis, K.C.

2002. Lebanon's Challenge: Reclaiming Memory and Independence. In Lebanon's Second Republic. Prospects for the Twenty-First Century, edited by Kail C. Ellis, pp. 1-13. University Press of Florida, Gainesville.

Hamilakis, Y.

2007. From Ethics to Politics. In Archaeology and Capitalism. From Ethics to Politics, edited by Yannis Hamilakis and Philip Duke, pp. 15-40. Left Coast Press, Walnut Creek, CA.

Hobsbawm, E.J., and T.O. Ranger (editors)

1983. The Invention of Tradition. Cambridge University Press, Cambridge.

Kaufman, A.

2004. Reviving Phoenicia. The Search for Identity in Lebanon. I.B. Tauris, London.

Naccache, A.F.

1998. Beirut's Memorycide. Hear no Evil, See no Evil. In Archaeology Under Fire. Nationalism, Politics and Heritage in the Eastern Mediterranean and Middle East, edited by Lynn Meskell, pp. 140-158. Routledge, London.

\section{NAGPRA}

n.d. http://www.nps.gov/history/nagpra/MANDATES/INDEX.HTM. U.S. National Park Service. Accessed 8 March 2008.

Nardella, B.M., and Y. Abbas

n.d. Conservation and Reconstruction in the Beirut Central District. http:// web.mit.edu/akpia/www/AKPsite/4.239/beruit/beirut.html. Accessed 6 March 2008.

Starzmann, M.T.

2008. Cultural Imperialism and Heritage Politics in the Event of Armed Conflict: Prospects for an "Activist Archaeology." Archaeologies: Journal of the World Archaeological Congress 4(3). doi:10.1007/s11759-008-9083-7.

\section{Additional Literature}

This list consists of literature that has had a significant influence on my own reflections and actions in those places where I have worked but in which I was not myself raised and socialized. These works have also played a role in shaping my own position with regard to the value of historical knowledge and consideration of the effects of historical reconstruction.

Därmann, I., and C. Jamme (editors)

2002. Fremderfahrung und Repräsentation. Velbrück Wissenschaft, Weilerswist. 
Gibson, M.

2007. Culture and Power. A History of Cultural Studies. Berg, Oxford.

Han, B.-C.

2005. Was ist Macht. Reclam, Stuttgart.

2005. Hyperkulturalität. Kultur und Globalisierung. Merve, Berlin.

Joas, $\mathrm{H}$.

2000. Kriege und Werte. Studien zur Gewaltgeschichte des 20. Jahrhunderts. Velbrück Wissenschaft, Weilerswist.

Kimmerle, $\mathrm{H}$.

2002. Interkulturelle Philosophie. Junius, Hamburg.

Langewiesche, D.

2008. Zeitenwende. Geschichtsdenken heute. Vandenhoeck und Rupprecht, Göttingen.

McGuire, R.H., and R. Navarrete

2005. Between Motorcycles and Rifles. In Global Archaeological Theory. Contextual Voices and Contemporary Thoughts, edited by Pedro P. Funari, Andrés Zarankin, and Emily Stovel, pp. 309-336. Kluwer, New York.

Winter, R., and P.V. Zima (editors)

2007. Kritische Theorie heute. Transcript, Bielefeld. 